\title{
Geo-Spatial Mapping of the Eastern Bushveld Rustenburg Layered Suite (RLS) in South Africa
}

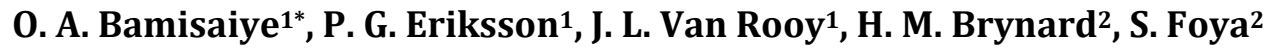 \\ ${ }^{1}$ Department of Geology, University of Pretoria, Pretoria, South Africa \\ ${ }^{2}$ Council for Geoscences, Pretoria, South Africa \\ Email: "adunseyi@gmail.com
}

Received 5 November 2015; accepted 27 May 2016; published 30 May 2016

Copyright (C) 2016 by authors and Scientific Research Publishing Inc.

This work is licensed under the Creative Commons Attribution International License (CC BY). http://creativecommons.org/licenses/by/4.0/

(c) (i) Open Access

\begin{abstract}
This paper focused on the results of the Trend Surface Analysis (TSA) of the Rustenburg Layered Suite (RLS) within the three major limbs of the Bushveld Complex. This second part focused on the Eastern Bushveld Complex and discussed the major trends, geometry and age relationship of the various structures within the Complex. The trend surface analysis of the Eastern Bushveld reveals that most of the residual positive structures occur as isolated closures with dome shape and are consistent with the location of the diapiric structures previously identified by geophysical and field mapping techniques.
\end{abstract}

\section{Keywords}

Eastern Bushveld, Geometry, Rustenburg Layered Suite, Trend Surface Analysis, Trend

\section{Introduction}

Trend surface analysis deals with the recognition of trends. This technique involves the estimation of the difference between regional pattern variations from local variation using least squared criteria. The regional surface derived is termed the large-scale component, while the residuals are referred to as the small-scale component [1]. Residual values are resolved by computing the difference between the value of the trend surface (large-scale component) at a point and the actual measured value at the same point. Trend surface analysis permits the appreciation of both regional and residual trends at each stratigraphic contact.

In this study the depth at each stratigraphic contact was determined from hundreds of well log data made ${ }^{*}$ Corresponding author. 
available by the Council for Geosciences, in South Africa. Depth of occurrence of each stratigraphic contact was interpreted from spatially distributed boreholes and processed using Trend Surface analysis (TSA) technique. Application of TSA technique to the Rustenburg Layered Suite (RLS) stratigraphic units shows stractigraphic contact irregularities that can be associated with folding and discontinuities that coincide remarkably with doming and faulting in the area. It has implications for constraining the relative timing and sequence of deformation events. It also provides information about the regional dip, morphology of individual structural features, and structural trends in the subsurface. The RLS occurs in layers (with thickness of about $8000 \mathrm{~km}$ ) that are comparable to stratigraphic horizons in sedimentary sections and are treated as such in this study. However, the maximum thickness under consideration in this study is limited to about $3000 \mathrm{~km}$ due to limitation of available data, most of the available boreholes were drilled for exploration purposes and few boreholes extend beyond $3000 \mathrm{~m}$ depth.

\section{Geology of the Eastern Bushveld Complex}

The RLS in the Eastern Bushveld intruded along a major regional unconformity between the Pretoria Group sediments, overlying residual zone rocks [2] and Rooiberg felsites [3]. The outcrops exhibit a complete stratigraphic section from harzburgite to fayalite- and apatite-bearing diorite [4]-[6] and dips steeply at about 60 degrees at the contact zone, and flatten out towards the centre. Outcrops in the Eastern Bushveld are well exposed due to the rugged topography [7]-[9]. RLS rocks are divided into five major stratigraphic units (Figure 1) which

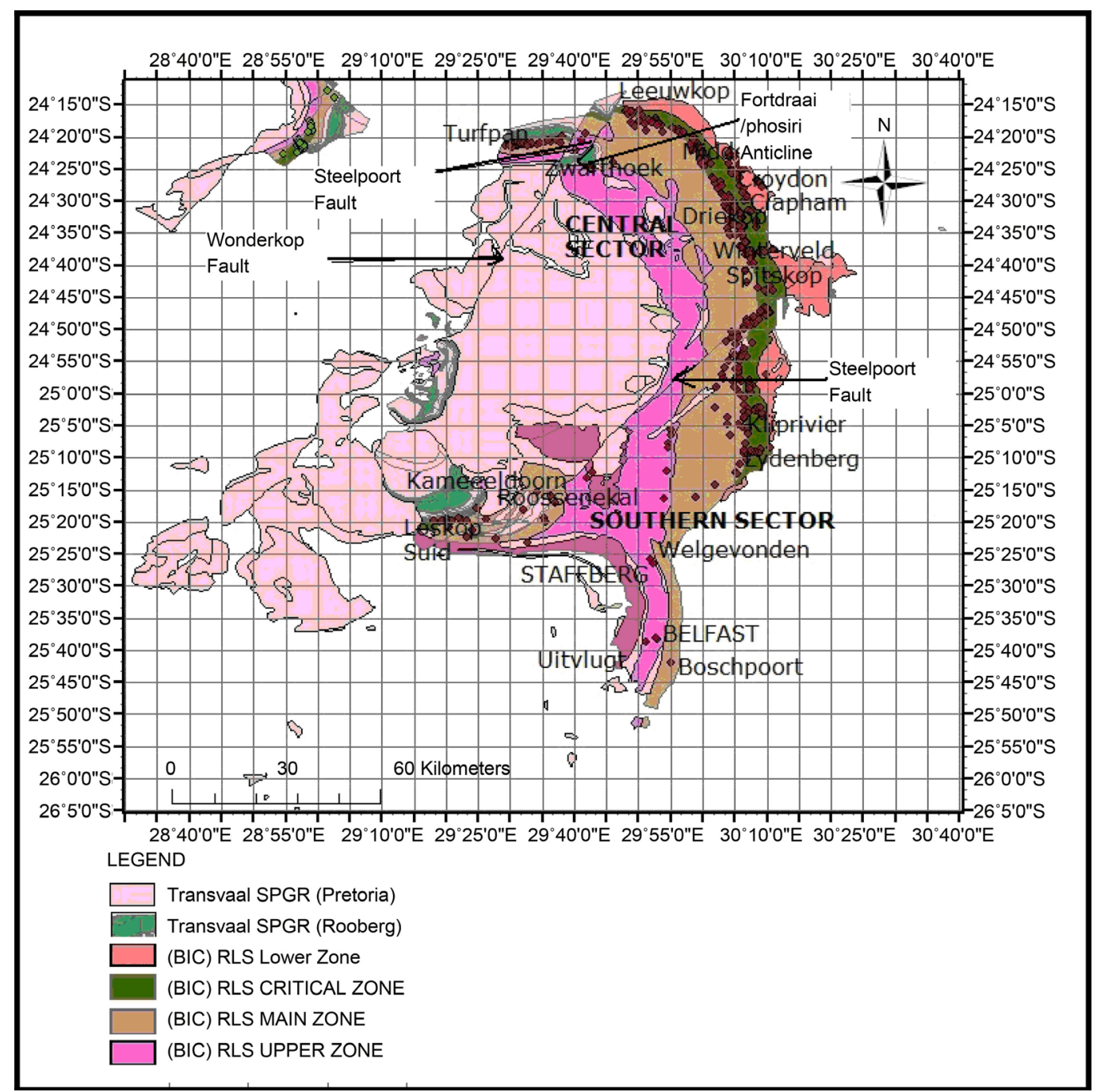

Figure 1. Geologic map of the Eastern Bushveld Complex with some farm names and borehole locations. 
include the Upper Zone, the Main Zone, the Critical Zone, the Lower Zone and the Marginal Zones [10]. The Upper Zone is characterized by gabbro with bands of magnetite. Twenty-five magnetitite layers were identified in the Eastern Bushveld Complex limb by [11]. The Magnetitite layers occur on Mphatlele farm, Kennedy's Vale farm, Krusirivier farm, Mapochsgronde farm, Welgevonden farm, Uitvlugt farm, Doornpoort farm and Zwartkop farm. This layer is important for its vanadium content.

Lithologic units that constitute the Main Zone in the Eastern Bushveld include the gabbro, norites, anorthosites and pyroxenites with the absence of olivine and chromite [12], while the thickness varies from $0-3000 \mathrm{~m}$. The Lower Zone is directly overlain by the Critical Zone [4]. The Lower Zone of the Eastern Bushveld Complex has been divided into lower pyroxenite, Harzburgite subzone, and Upper Pyroxenite. The Lower Zone thickness varies with the structure of the floor rock, attaining about $1584 \mathrm{~m}$ in thickness around the Olifants River Trough.

The Marginal Zones consist of mainly norites with minor pyroxenite [13], and occurs in contact with metasedimentary rocks of the Transvaal Super Group. Its occurrence is influenced by modifications on the sedimentary floor by folds, faults and attenuation of overlying rocks [14]. The RLS in the eastern Bushveld is penetrated by floor rock domes believed to have been formed by diapiric processes [15].

\section{Method}

Borehole log data were obtained from the Council of Geoscience, Pretoria, South Africa, stratigraphic contact top (depth at which each stratigraphic contact was encountered in the borholes) were interpreted from the lithologic peaks. The depth values at each stratigraphic contact were contoured to generate a continuous and regional trend surface in Rockworks ${ }^{\circledR} 15$ software environment. The residual details were extracted from the regional trend surface using grid math algorithm. This was followed by careful interpretation of contact features of each contact. Detail description of the method is given in another paper already submitted for publication.

\section{Results}

\subsection{Upper and Main Zone Residual Structure and Trend in the Northeastern Bushveld}

The Upper and Main Zone residual structures in Figure 2 show both positive and negative structural domains. The western side of the Fortraai/Phosiri Anticline shows contours that open to the west (probably indicating continuation to the west) around Rooibokbult farm. The positive domain (which coincides with Katkloof structure) in the northeastern part of the Wonderkop Fault is adjacent to an extensive SE trending negative domain. The Fortraai/Phosiri Anticline coincides with another positive domain. The eastern part of the Fortraai/Phosiri Anticline shows close structure contours indicating steep slope towards the Eerste regt farm. These contours coincide with the location of an N-S trending river channel on the geological map consequently, confirming the presence of the N-S trending structure that separates the Fortraai/Phosiri Anticline from the negative structural domain in Eerste regt area (see Figure 2).

The Main Zone residual structures in Figure 2(b) are marked by steep-sided synclinal structure of about $2 \mathrm{~km}$, around Middelpunt farm. Adjacent to this structure on the western side is an isolated structural high. Another steep sided negative structure occurs in the southwest, adjacent to the Fortdraai/Phosiri Anticline.

The area around the Zwarthoek farm adjacent to the Eersteregt in Figure 3 shows N-S trending close contours west Fortraai/Phosiri anticline (on Zwarthoek) and around Katkloof structure (on Middlepunt farm) amidst predominant E-W structural trend in the Northeastern Bushveld Complex.

\subsection{Northeastern Bushveld Residual Isopach}

Upper Zone residual isopach map for the Northeastern Bushveld Complex in Figure 4(a) indicates isolated positive thickness around the Mphatlele location in the north and negative thickness towards the southeast. East-West thickening trend dominates the northern part of the Northeastern Bushveld. Upper Zone isopach trend maps as indicated in Figure 4(a) with NNW trend at the centre. The Merensky Reef isopach also exhibits a weak NNW thinning trend.

The Main Zone residual isopach maps in Figure 4(b) show a similar residual domain with a central NNW oriented positive thickening around Leeuwkop and Middlepunt farm. This area is dominated by a dome-shaped structure that slopes eastwards into adjacent structural low domain.

The Merensky residual isopachs are marked by negative thickness residuals in the west and positive residual 


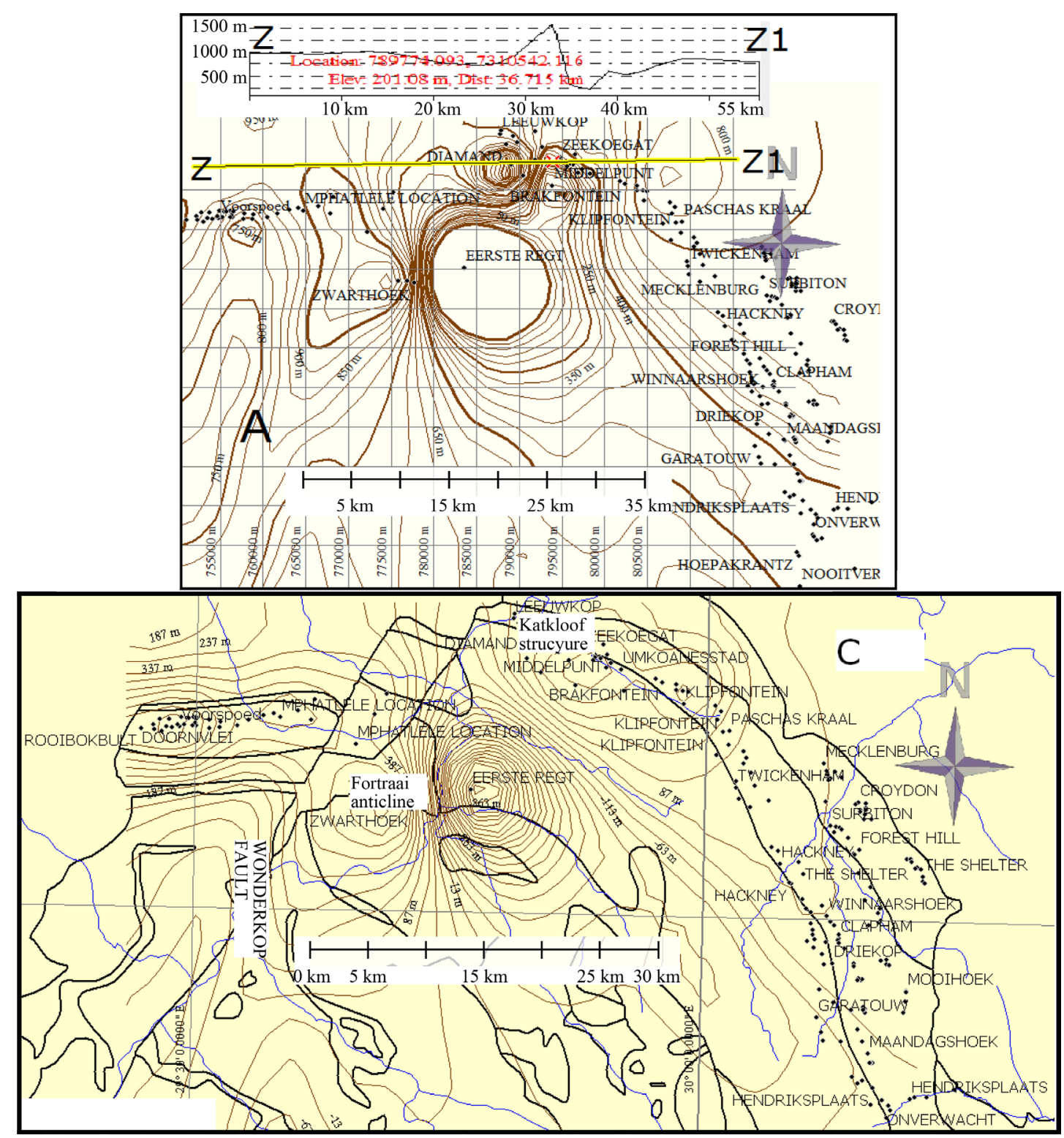

Figure 2. Main Zone residual structure map (A) with profile Z-Z1 around Katkloof structure and the northeastern Bushveld Upper Zone third orderwith draped geological contact (black lines) and rivers (blue) flowing mostly southward. Black dots represent borehole points.

in the east. The negative residual portion is also bounded on both sides by fault zones. Areas around the Fortdraai/Phosiri Anticline coincide with a syncline on the residual structural map and anticline on the residual isopach map. A small residual negative structure also exists on Voorspoed farm; this structure shows up as small positive thickness on the thickness residual map thus supporting inverse structure and thickness correlation of both trend and residual structures.

\subsection{Relationship between Structure and Isopach of Northeastern Bushveld}

The relationship between thickness and structure of each of the stratigraphic units in the Northeastern Bushveld Complex indicates that most of the structures developed independently, (or the units were affected by later tectonic activities), consequently, the structure and thickness trend of each of the units in the Northeastern Bushveld Complex did not show a significant inverse relationship. This means that these structures are not related to deposition of the RLS rocks or are predominantly post-Bushveld. 
There are few similarities between the structure on the Upper Zone and Main Zone units. However, the thickening trend between the Upper Zone and the Main Zone varies strongly. While the structures indicate more of a NNW trend, the thickness shows more of an E-W trend. Conversely, the Main Zone and the Archaean floor rock structures show some similarities as indicated in Figure 5, probably indicating basement control on the RLS rocks.

\subsection{Residual Structure and Isopach of Central Part of the Eastern Bushveld Complex}

Residual structures include the depression (central dipping) at Kennedy's Vale in the east and the adjacent structural high at Spitskop with few dome-shaped closures (that coincides with the location of diapirs on the geologic map) around the eastern margin (see Figure 6(a) and Figure 6(b)).

The Upper Zone and Main Zone (Figure 7 and Figure 8) show positive thickening in the centre and thins out to the northwest on both the residual and trend isopach maps.

\subsection{Southeastern Bushveld Residual Structure}

A few positive and negative structures are evident on Upper Zone stratigraphic unit of Southeastern Bushveld
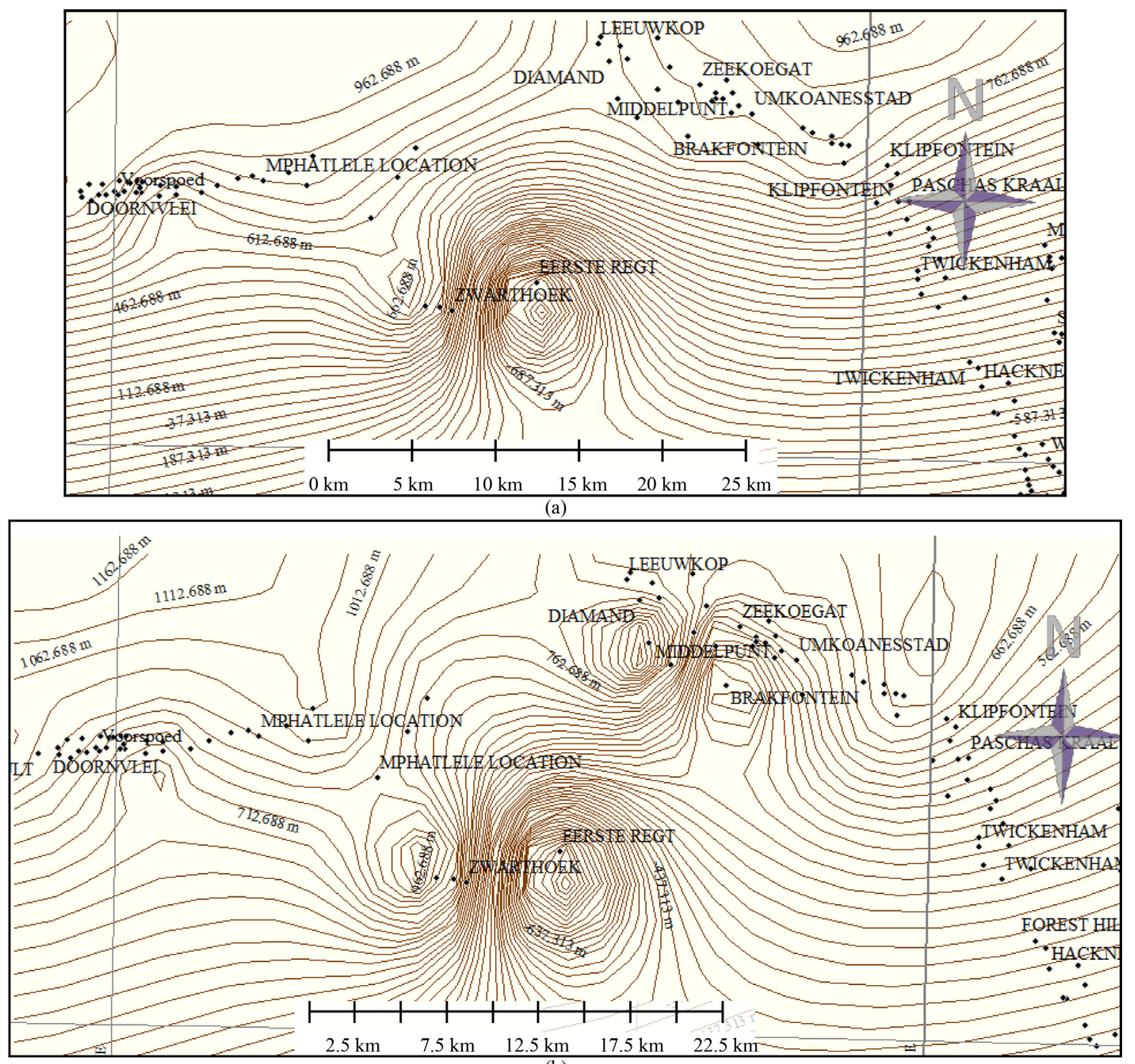

(b)

Figure 3. (a) The northeastern Bushveld Upper Zone second order structural trend maps; (b) First order Main Zone structural trend of the northeastern Bushveld Complex. 


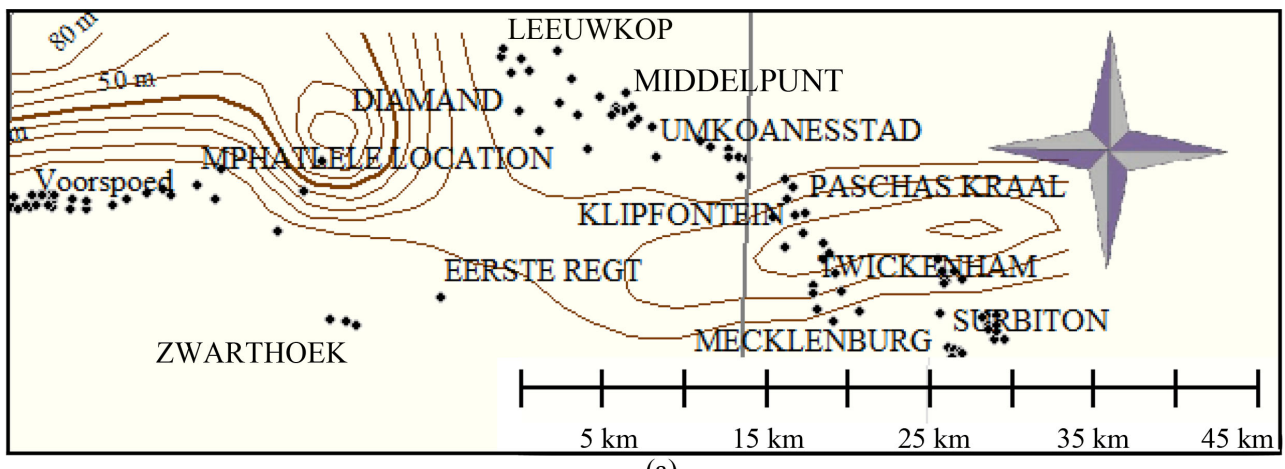

(a)

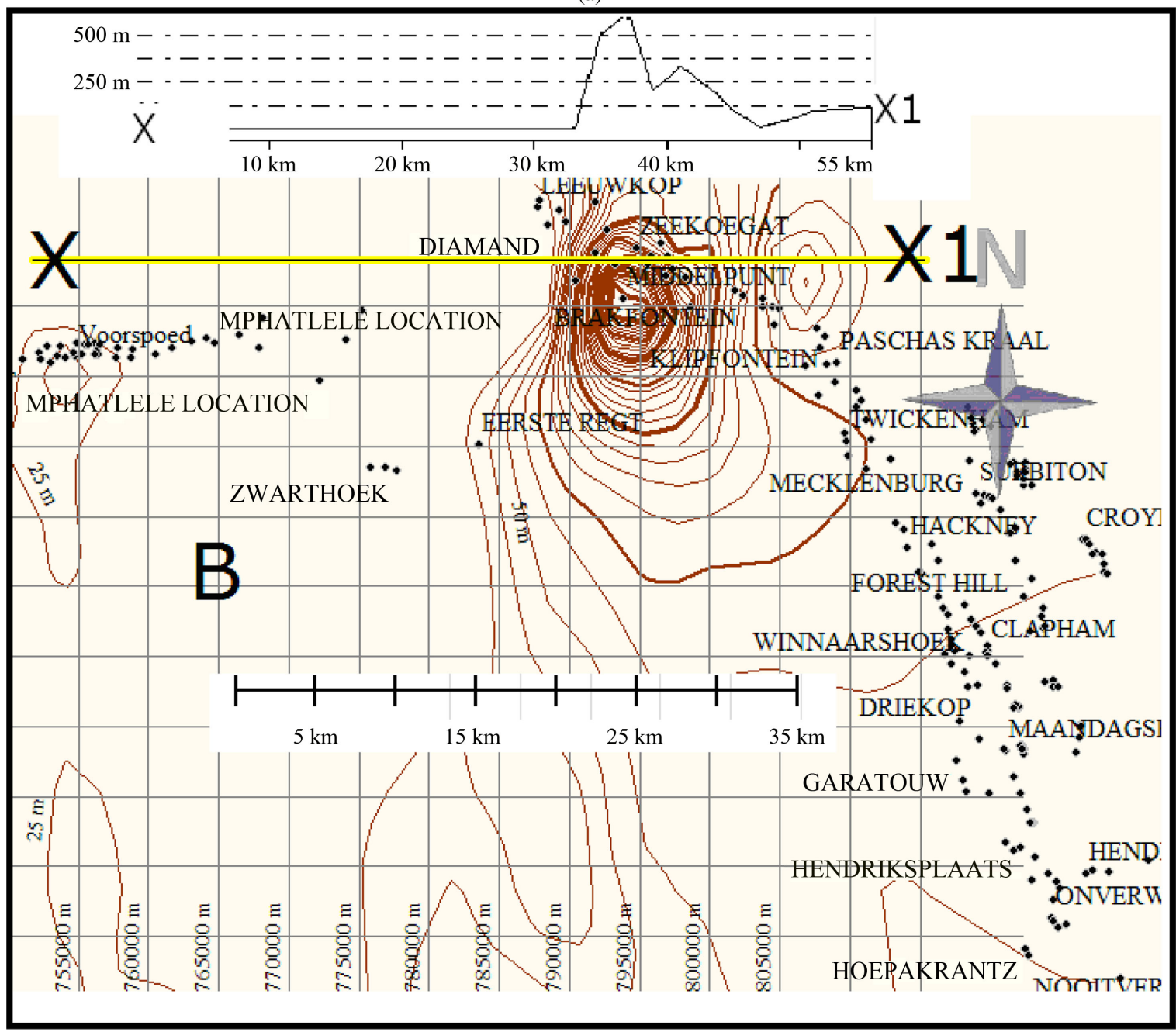

(b)

Figure 4. (a) Second order Upper Zone isopach trend; (b) Main Zone isopach B with profile X-X1 across Katkloof structure in the northeastern part of eastern Bushveld.

Complex as shown in Figure 9 and Figure 10. The Groblersdal sector (east of Mineral range farm) consists of a synclinal structure, while the immediate east of this synclinal structure consists of gradually increasing northeast elongate positive domain. Further eastwards in Figure 10(a) and Figure 10(b) are extensive positive domains that open to the east, implying possible continuation of the positive domain to the east. Within this extensive positive domain are three isolated strong positive residuals with dome shape, one occur at the centre of Mineral range i.e., north of Welgevonden. The other two residual structures occur in the extreme eastern part. The 


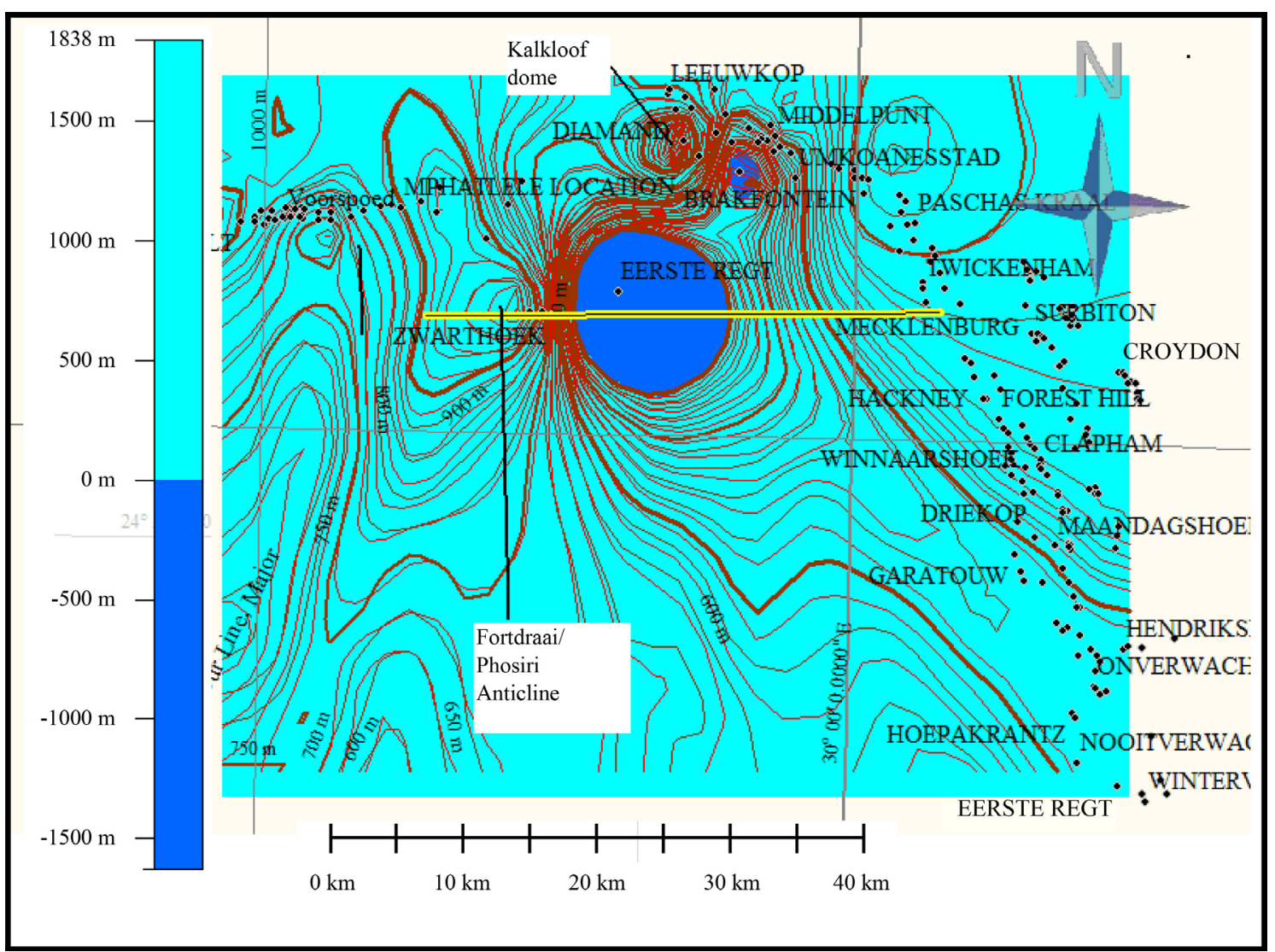

Figure 5. Showing close correlation between Archaean floor structure contours (brown) and Main Zone structure contour (black) of north-eastern Bushveld Complex. (Contour interval is 50).

southern parts of Stoffberg (east of Welgevonden) in southeastern Bushveld are marked by strong positive domain separated from the Mineral range positive domain by a negative domain, which marks the location of the Laersdrift Fault.

Main Zone residual structure contour in Figure 10(b) exhibit a few small structural negative domains that slope to the west around Buffelshoek and Der Brochen farm south of Steelpoort. Area around the Globlersdal sector of the Loskop suid farm also exhibits negative domain.

The pattern on the residual structure map for the Main Zone up to the Achaean granite surface is the same while the residual isopach varies randomly as indicated in (Figure 10).

\subsection{Southeastern Bushveld Residual Isopach}

Isolated positive thickness domains can be identified on the Upper Zone residual isopach map. The N-S aligned structures dominate the central part of the Southeastern Bushveld Complex (see Figure 11(a)). Steep slopes exist around these structures to the east and more gradual slope in the western part. The eastern parts around Kliprivier farm is marked by negative thickness, while the Groblersdal section is marked by an eastward thickening trend. The Main Zone residual isopach map in Figure 11(b) reveals a prominent positive domain in the eastern part of Mineral range and around Globerlersdal section, which geographically coincides with areas with negative domain on the residual structure maps.

The Merensky Reef thickens prominently around the southern parts of Steelpoort especially around Richmond and Mareeburg farms (as indicated in Figure 11(b)). The thickening, however, terminates abruptly to the north around Steelpoort fault.

\subsection{Southeastern Bushveld Structure Trend}

The Upper Zone first order structure trend of the Southeastern Bushveld area in Figure 11 can be separated into 
four broad trends; the Groblersdal synclinal area, the Stoffberg area dominated by an anticlinal structures, the Kliprivier area with anticlinal closures that open to the east at the central (i.e. east of the Groblersdal area), with increasing structure high and E-W trend.
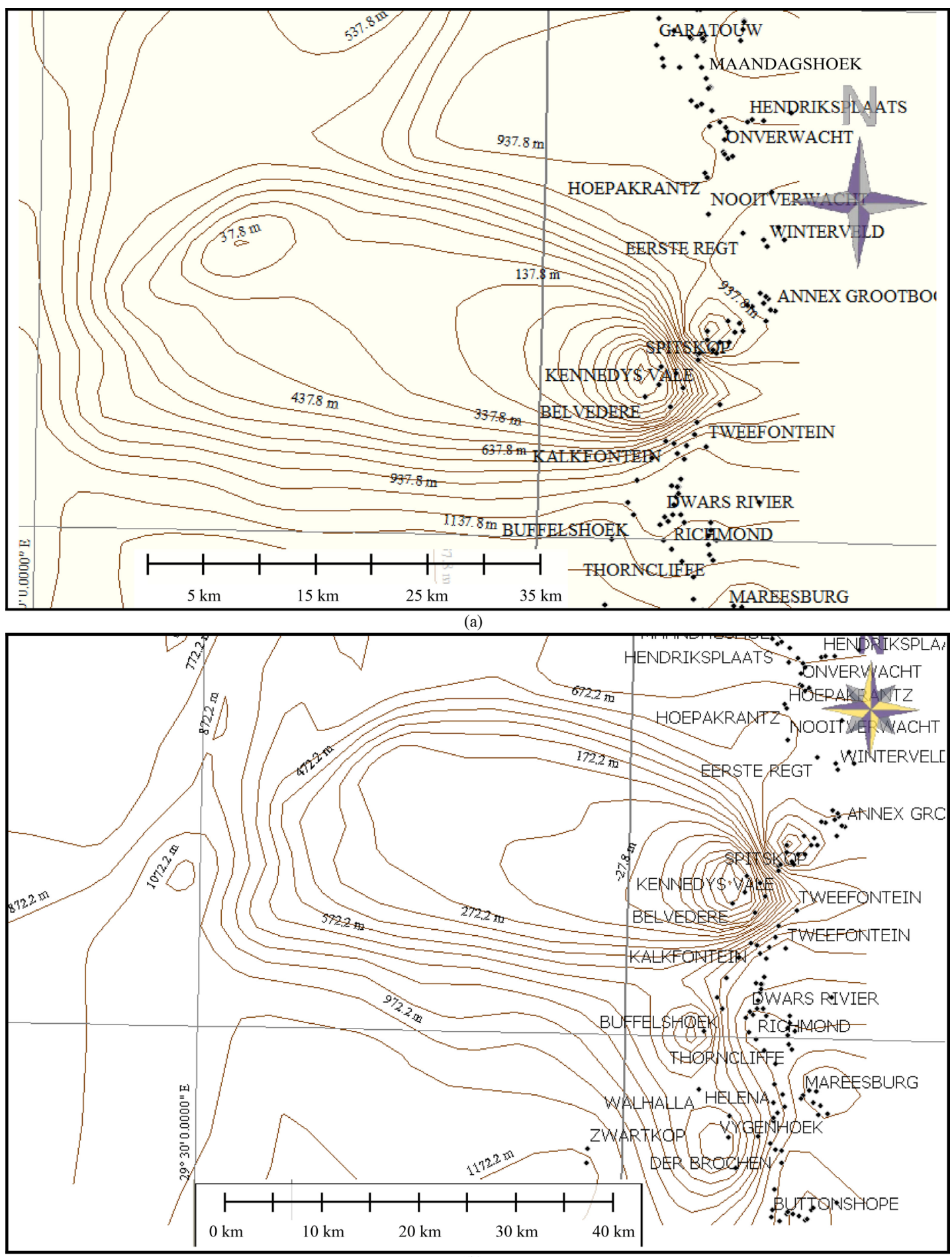

(b)

Figure 6. (a) Second order residual structure contour map for Upper Zone unit of central parts of eastern Bushveld; (b) Second order residual structure contour maps for the Main Zone unit of the central parts of eastern Bushveld Complex. 
O. A. Bamisaiye et al.
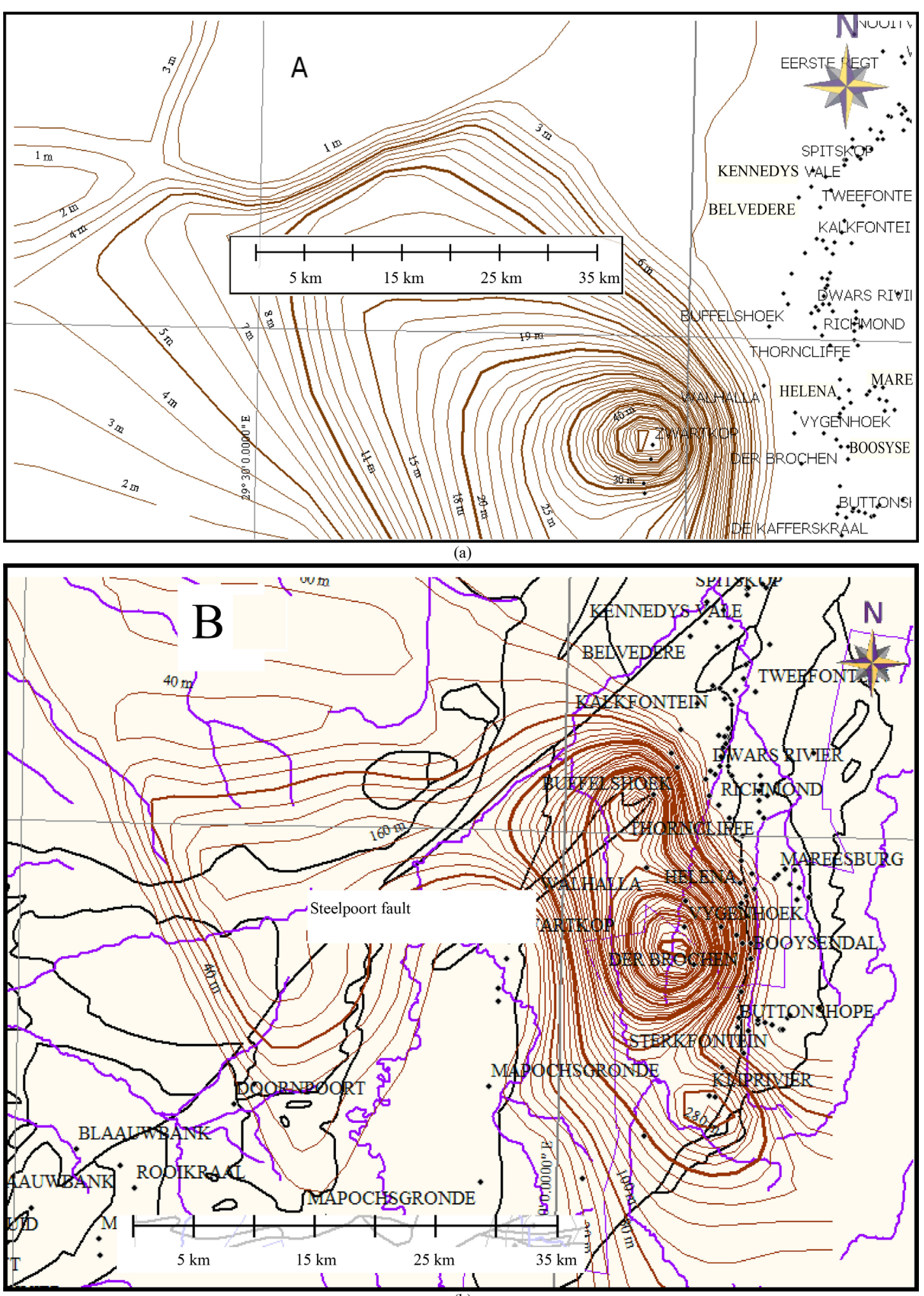

(b)

Figure 7. (a) Second order residual isopach contour map for the Upper Zone unit of the central parts of eastern Bushveld Complex (contour interval 1); (b) Residual isopach contour maps for the Main Zone unit of the central parts of eastern Bushveld Complex (contour interval 20). B indicates the rivers and the geological contact draped over the residual isolines, rivers geometry strongly correlate. 


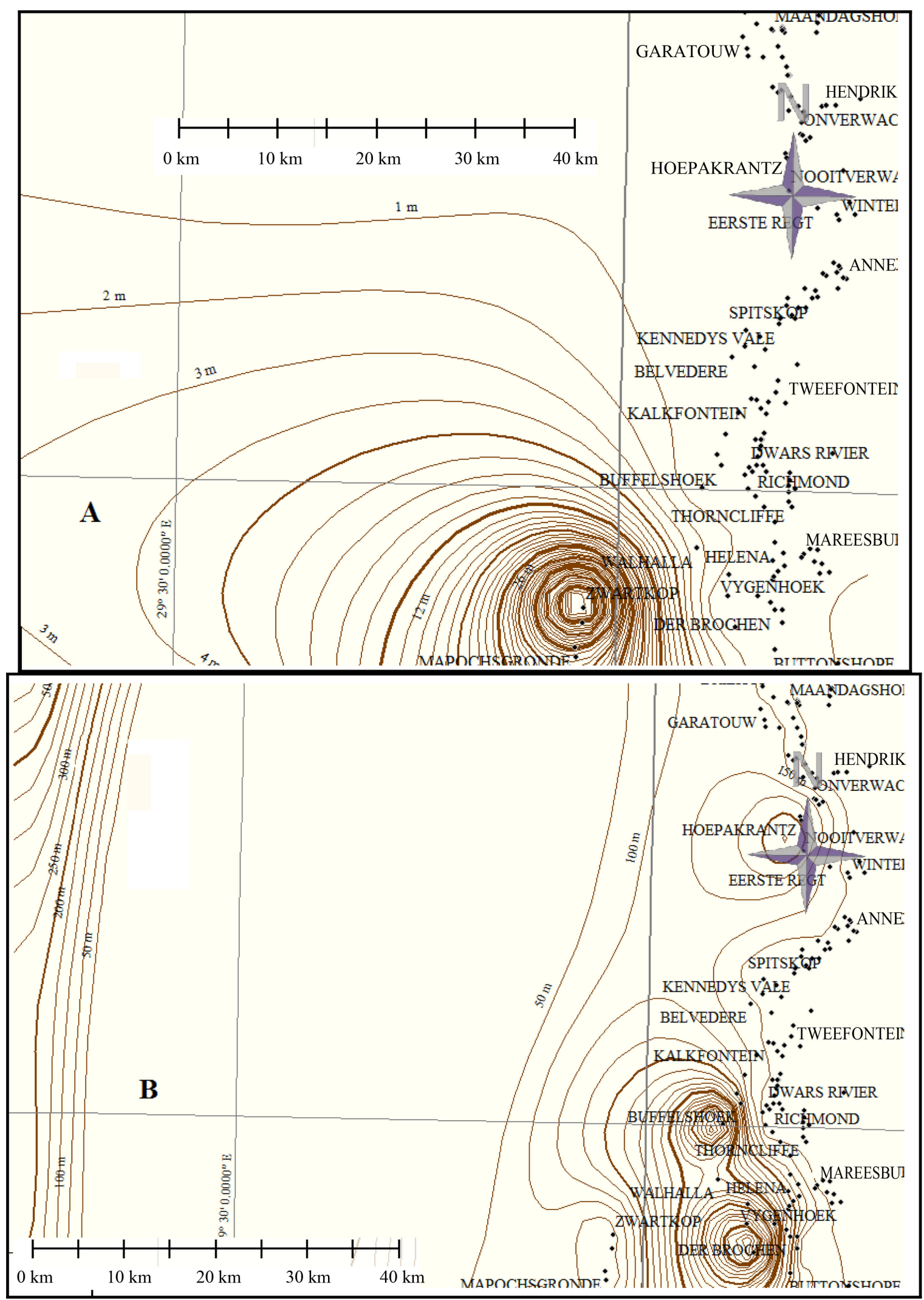

Figure 8. (A) is Upper Zone isopach trend, (B) shows Main Zone isopach trend of central parts of the eastern Bushveld Complex. 


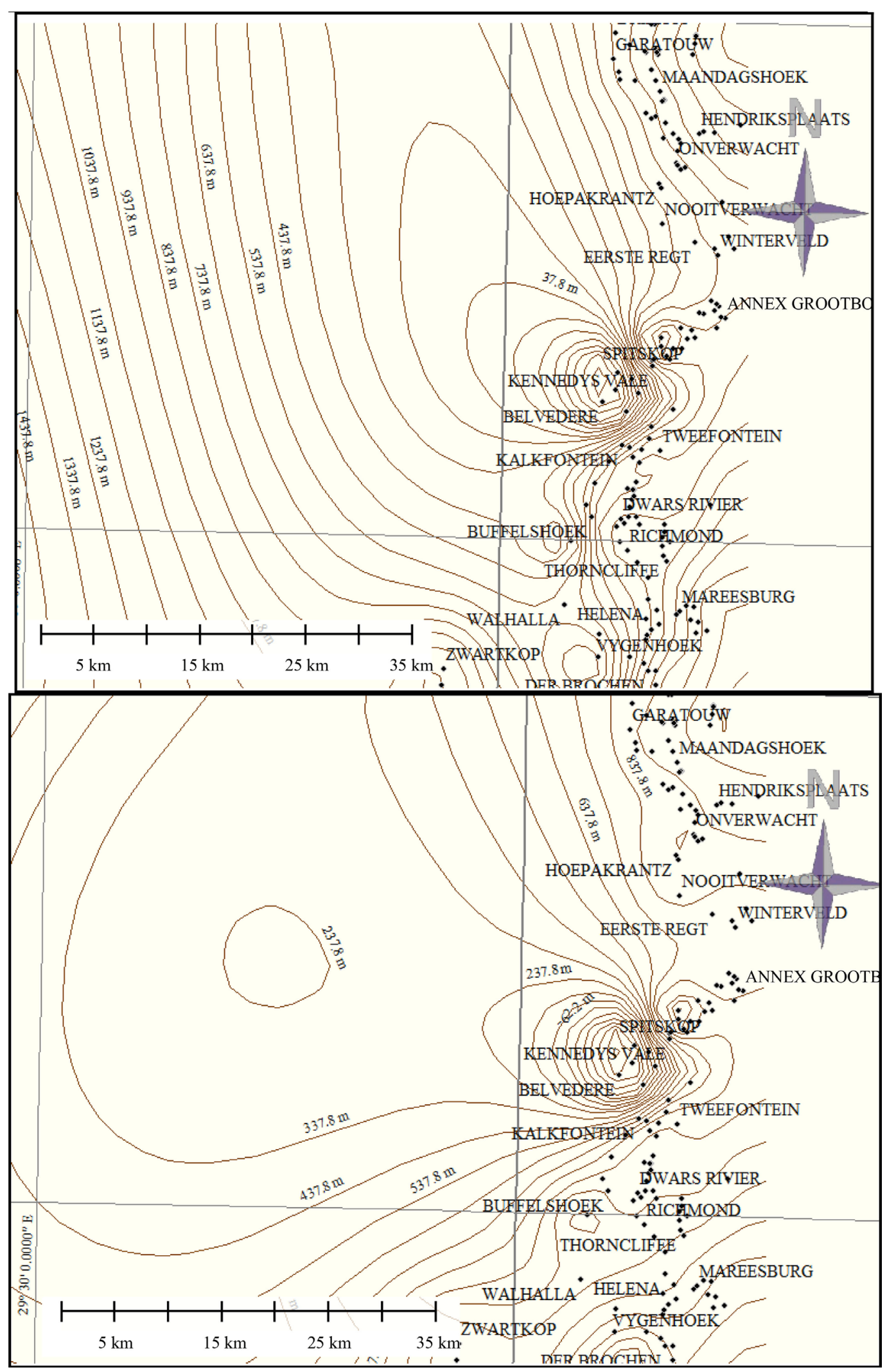

Figure 9. Structure trend for the Upper Zone (up) and the Main Zone (down) of central parts of the eastern Bushveld Complex. 

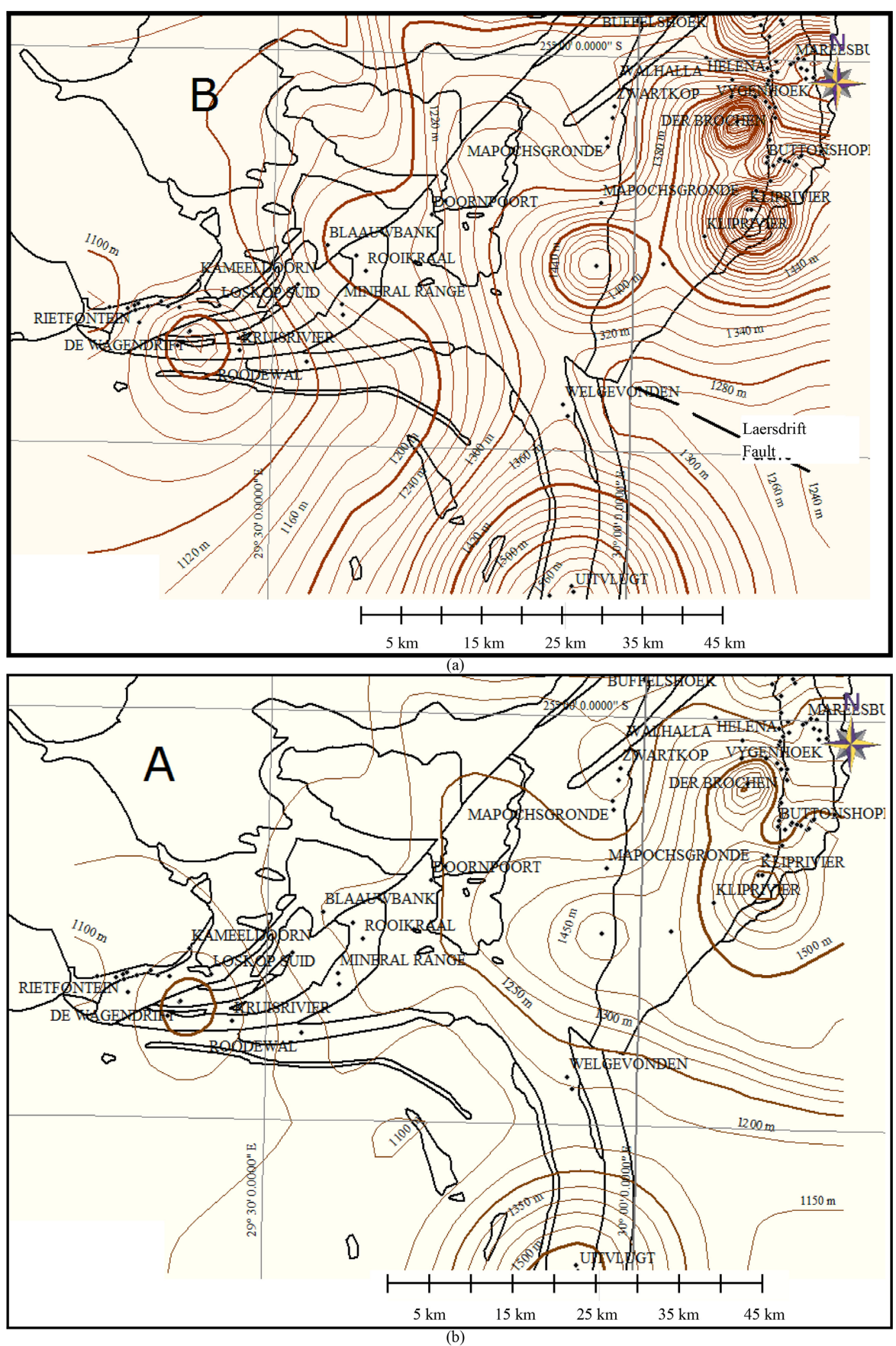

Figure 10. (a) Upper Zone residual structure map B of southeastern part of the eastern Bushveld Complex. (Contour interval 20). (b) Main Zone residual structure map A of southeastern part of the eastern Bushveld Complex. Contour interval 50. 


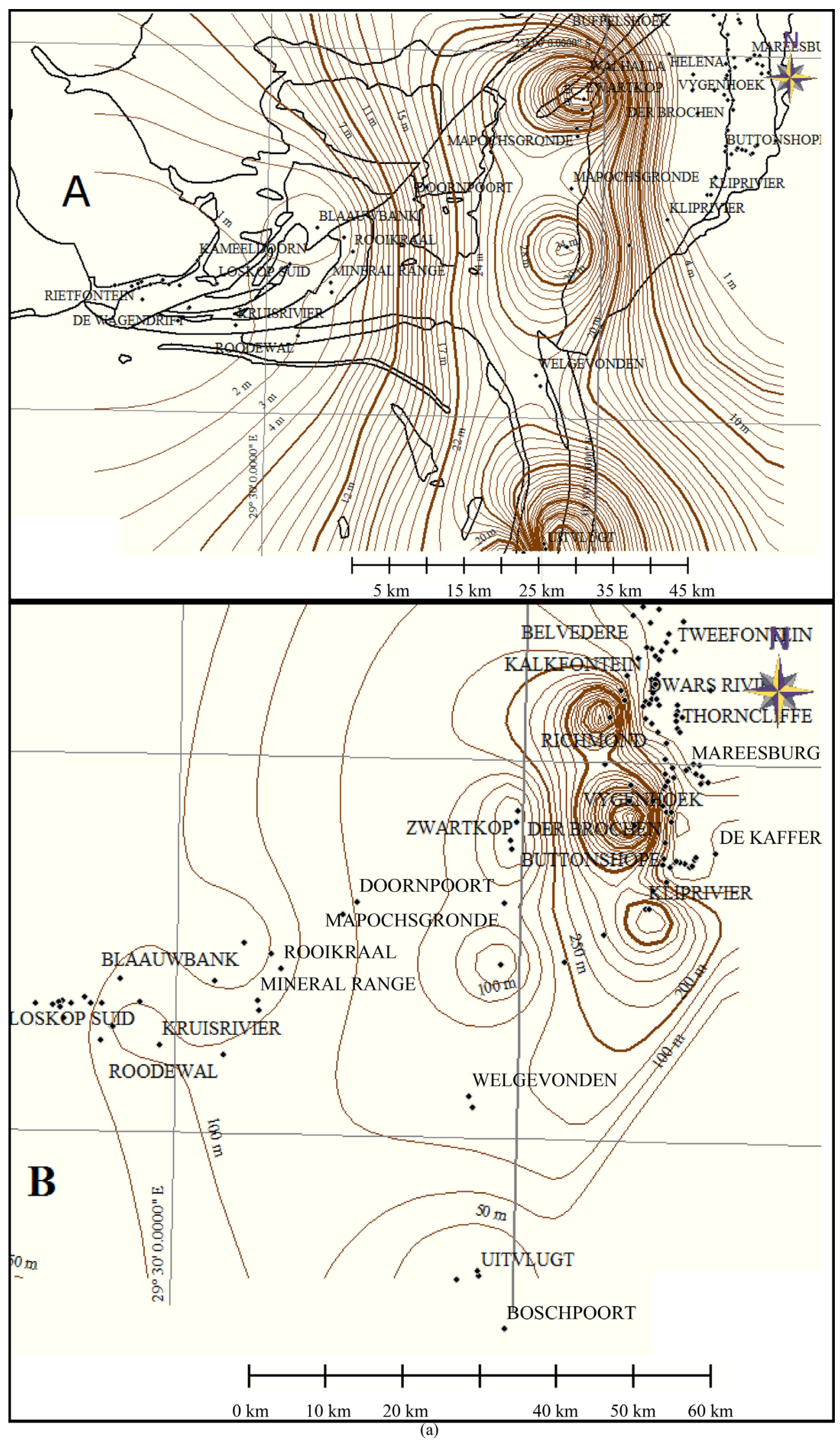




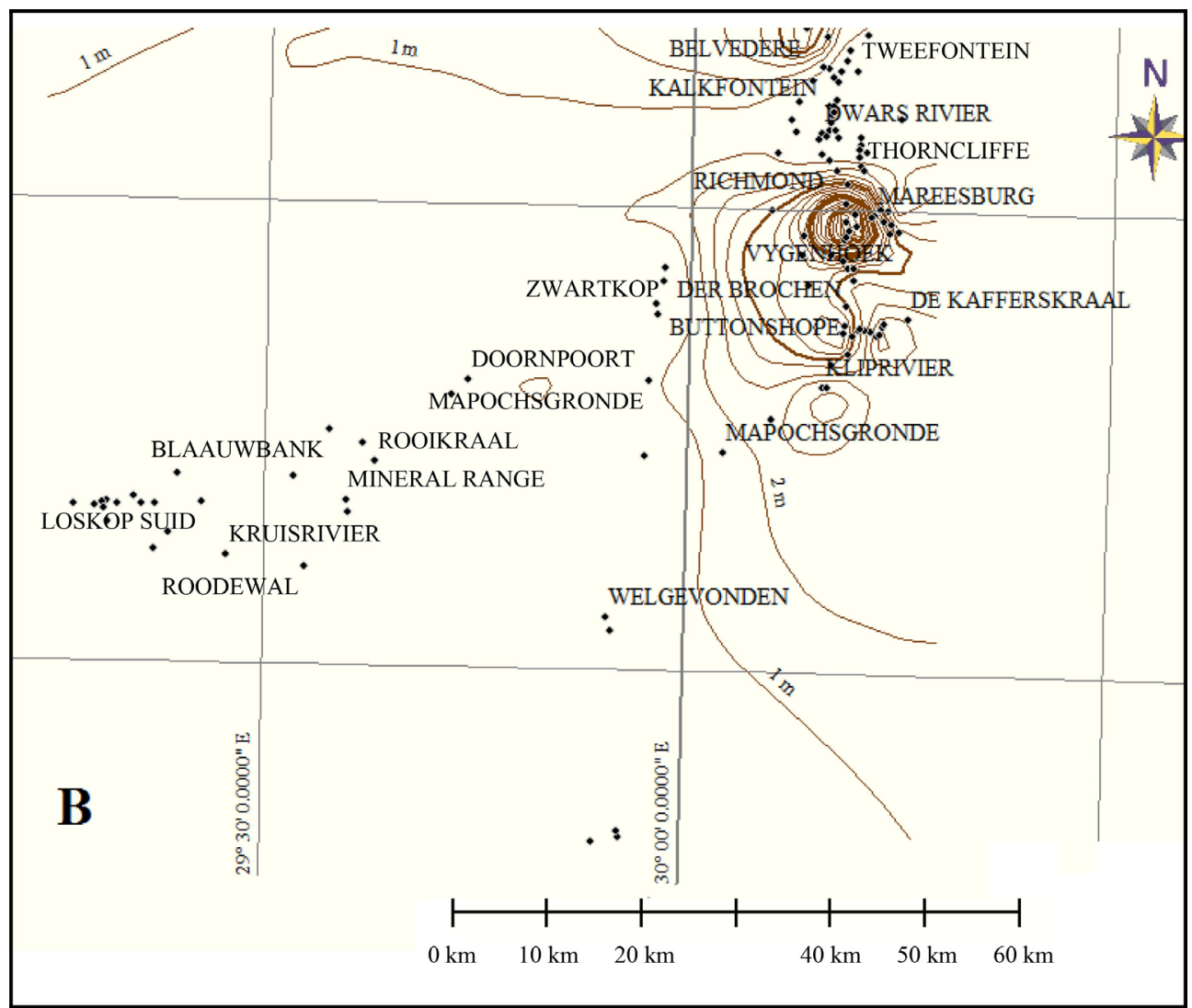

(b)

Figure 11. (a) Upper Zone isopach trend surface A of the southeastern Bushveld Complex. Main Zone isopach trend of the southeastern Bushveld Complex B. Note the concentration of dome shaped structures along the edges; (b) Merensky Unit second order B isopach trend map of parts of the southeastern Bushveld Complex.

The Main Zone isopach trend in Figure 11 is marked by NNW thickening around the southern parts of Steelpoort. The area also coincides with the shallow dipping part of the Eastern Bushveld Complex on the geological map.

\subsection{Southeastern Bushveld Isopach Trend}

The Upper Zone isopach trend map in Figure 9 exhibit prominent N-S and NNW-SSE trend and dips to the centre (around Welgenonden). However, on Main Zone residual isopach, the former north-south structure positive domain in the centre now coincides with the absence of the Zone. The Main Zone show strong inverse correlation between structure and isopach. Main Zone trend surface reveals a dominant NNW trend at the northeastern part in Figure 11(b). The isopach lines run mostly N-S and NNW-SSE on Main Zone isopach map and NE on Critical Zone isopach map.

\subsection{Relationship between Trend Residual Structure and Isopach of Southeastern Bushveld Complex}

The residual structure and isopach maps exhibit inverse correlation in the eastern section, while the other parts show a similar relationship in structure and thickness. Most of the small dome-like structures correspond to the location of diapirs on the geological map. On the trend surface maps the general trend is increasingly east verging positive structure with west dip. Inverse correlation exists between the structure and isopach residual of the Upper and Main Zone indicating that most part of the Southeastern Bushveld Complex of the Eastern Bushveld Complex are probably pre-Bushveld structures that were reactivated during RLS emplacement. Upper Zone structure 

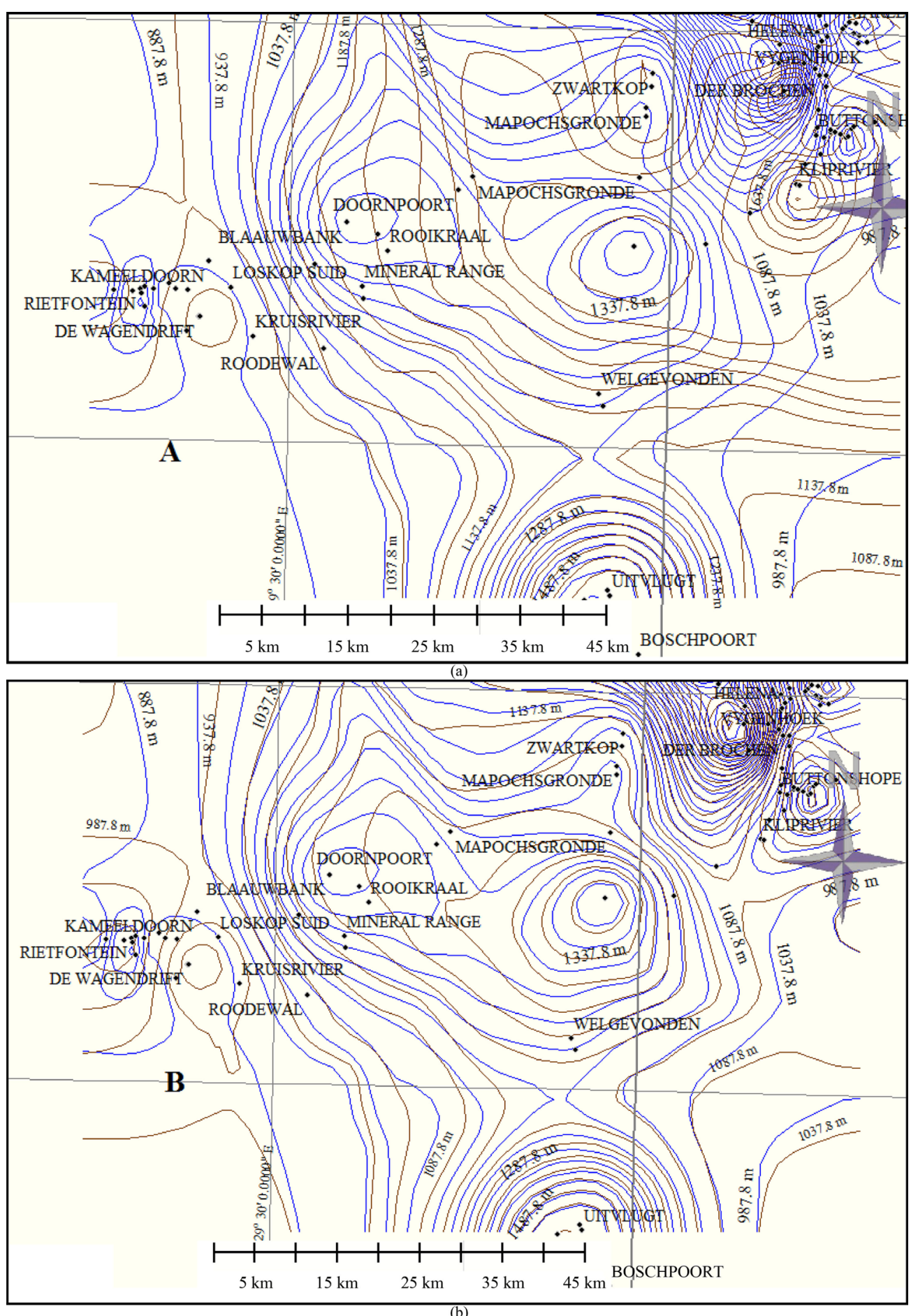

Figure 12. (A) is draped structure contour map of Upper Zone on Achaean floor rock structure contour map. (B) indicates correlation between the Achaean floor and Main Zone base interval structure contour of the southwestern Bushveld Complex.

interval only shows close similarities with the Archean floor in the southern and western parts. However, the Main Zone base and floor rock interval show close similarities as indicated in Figure 12(a), this indicates strong floor rock influence on the RLS units up to the base of the Main Zone. Figure 12(b) however, indicates that the Upper Zone structure interval only shows close similarities with the Archean floor in the southern and western 
parts and not in the northern part.

\section{Discussion}

The results of this study provide both local and regional perspectives of the geometry of the RLS which coincides remarkably with the structural and geological studies in the area. The trend surface analysis of the Eastern Bushveld reveals that most of the positive structures occur as isolated closures with dome-like shape and mostly coincide with the location of the diapiric structures as reported by [16]-[18]. These structures dominate the northern parts and the edges in the Northeastern Bushveld Complex and occur at the margins of the central and southeastern parts of the Complex.

Negative structure domains occur at the central part of the Complex around Kennedy's Vale and around the East Regt in the north-central part, i.e. adjacent to Fortdraai anticline was also reported in mining reports. The basal part of the Main Zone and the top of the Archaean floor shows a similar pattern in the Northeastern and at the Southeastern parts; indicating strong basement control probably modified by the emplacement of RLS rocks.

The Complex dips to the centre from the margins, while the southeastern part dips to the north of the centre of the Complex. The Northeastern Bushveld exhibits a strong NNW structural trend at the centre and east-west thickening trend, while the southeastern part trends mostly N-S.

The geometry and thickness of RLS are also controlled by the presence of valleys and positive physiographic elements during its emplacement and can be attributed to alternating tension and compression [15] [18] [19]. Faulting and up doming are more prominent in lower units of RLS (i.e. from the base of the Main Zone to the Archean floor), at the margins and in the southern parts, similar observation was reported by [15]. The RLS is thick along deep-rooted valley systems that were scoured into pre-Bushveld rocks or the Transvaal sequence in which it is emplaced.

\section{Conclusion}

The result obtained from this investigation correlate with the result obtained from previous field studies and geophysical investigation in the area. Subtle subsurface structural features were also revealed and validated. This confirms the validity of the method.

\section{Acknowledgements}

The authors are grateful to the University of Pretoria for financial support and the management and staffs of the Council for Geosciences, Pretoria for providing data and software facilities.

\section{References}

[1] Bove, F.J, (1981) Trend Surface Analysis and Lowland Classic Maya Collapse. American Antiquity, 46, 93-112. http://dx.doi.org/10.2307/279989

[2] Cawthorn, R.G. (2013) The Residual or Roof Zone of the Bushveld Complex, South Africa. Journal of Petrology, 54, 1875-1900. http://dx.doi.org/10.1093/petrology/egt034

[3] Cheney, E.S. and Twist, D. (1991) The Conformable Emplacement of the Bushveld Mafic Rocks along a Regional Unconformity in the Transvaal Succession of South Africa. Precambrian Research, 52, 115-132. http://dx.doi.org/10.1016/0301-9268(91)90016-4

[4] Cameron, E.N. (1978) The Lower Zone of the Eastern Bushveld Complex in the Olifants River Trough. Journal of Petrology, 19, 437-462. http://dx.doi.org/10.1093/petrology/19.3.437

[5] Cameron, E.N. (1980) Evolution of the Lower Critical Zone, Central Sector, Eastern Bushveld Complex, and Its Chromite Deposits. Economic Geology, 75, 845-871. http://dx.doi.org/10.2113/gsecongeo.75.6.845

[6] Cameron, E.N. (1982) The Upper Critical Zone of the Eastern Bushveld Complex; Precursor of the Merensky Reef. Economic Geology, 77, 1307-1327. http://dx.doi.org/10.2113/gsecongeo.77.6.1307

[7] Von Gruenewaldt, G. (1973) The Main and Upper Zones of the Bushveld Complex in the Roossenekal Area, Eastern Transvaal. Transactions of the Geological Society of South Africa, 76, 207-227.

[8] Sharpe, M. (1981) The Chronology of Magma Influxes to the Eastern Compartment of the Bushveld Complex as Exemplified by Its Marginal Border Groups. Journal of the Geological Society, 138, 307-326. http://dx.doi.org/10.1144/gsjgs.138.3.0307 
[9] Molyneux, T. (2008) Compilation on a Scale of 1:50000 of the Geology of the Eastern Compartment of the Bushveld Complex. Special Publication, 1.

[10] SACS (SOUTH AFRICA COMMITTEE FOR STRATIGRAPHY) (1980) Stratigraphy of South Africa Part 1: Lithostratigraphy of the Republic of South Africa, South West Africa/Namibia and the Republics of Bophuthatswana, Transkei and Venda. Handbook Geological Survey South Africa, Pretoria.

[11] Molyneux, T. (1974) A Geological Investigation of the Bushveld Complex in Sekhukhuneland and Part of the Steelpoort Valley. Transactions of the Geological Society of South Africa, 77, 329-338.

[12] Kinnaird, J.A. (2005) The Bushveld Large Igneous Province. Review Paper, The University of the Witwatersrand, Johannesburg, $39 \mathrm{p}$.

[13] Cawthorn, R., Eales, H., Walraven, F., Uken, R. and Watkeys, M. (2006) The Bushveld Complex. The Geology of South Africa, 691, 261-281.

[14] Uken, R. and Watkeys, M.K. (1997) Diapirism Initiated by the Bushveld Complex, South Africa. Geology, 25, 723726. http://dx.doi.org/10.1130/0091-7613(1997)025<0723:DIBTBC >2.3.CO;2

[15] Uken, R. (1998) The Geology and Structure of the Bushveld Complex Metamorphic Aureole in the Olifants River Area. University of Natal, Durban.

[16] Button, A. (1978) Diapiric Structures in the Bushveld, North-Eastern Transvaal. Econ. Geol. Res. Unit, Univ. Witwatersrand, In! Circ 123, 6 p.

[17] Sharpe, M.R. and Snyman, J.A. (1980) A Model for the Emplacement of the Eastern Compartment of the Bushveld Complex. Tectonophysics, 65, 85-110. http://dx.doi.org/10.1016/0040-1951(80)90225-5

[18] Holzer, L., Barton, J., Paya, B. and Kramers, J. (1999) Tectonothermal History of the Western Part of the Limpopo Belt: Tectonic Models and New Perspectives. Journal of African Earth Sciences, 28, 383-402. http://dx.doi.org/10.1016/S0899-5362(99)00011-1

[19] Bumby, A., Eriksson, P. and Van der merwe, R. (1998) Compressive Deformation in the Floor Rocks to the Bushveld Complex (South Africa): Evidence from the Rustenburg Fault Zone. Journal of African Earth Sciences, 27, 307-330. http://dx.doi.org/10.1016/S0899-5362(98)00065-7 